\title{
Investors' Preference towards Life Insurance Corporation of India
}

\author{
B. Sumathisri ${ }^{1}$ \\ ${ }^{1}$ Department of Commerce and Management Studies, Srinivasa Ramanujan Centre, SASTRA University, \\ Kumbakonam, India \\ Correspondence: Dr. B. Sumathisri, Department of Commerce and Management Studies, Srinivasa Ramanujan \\ Centre, SASTRA University, Kumbakonam, 612 001, India. \\ Received: July 11, 2017 \\ doi:10.20849/ajsss.v2i3.174 \\ Accepted: July 25, 2017 \\ Online Published: September 12, 2017 \\ URL: https://doi.org/10.20849/ajsss.v2i3.174
}

\begin{abstract}
Investments are both important and useful in the context of present day conditions of the economy. It is a common saying "One paisa saved is one paisa earned". Life is a roller coaster ride and is full of twists and turns. Insurance policies are to safeguard against the uncertainties of life. The insurance principle comes to be more and more used and useful in modern affairs. Not only does it serve the ends of individuals, or groups, it tends to pervade and to transform modern social order, too. At this juncture, the extent to which Life Insurance goes to attract the investors has been undertaken in this study. The analysis of the data evidenced that investment were not determined by either income or education of the respondents, instead they understood the necessity of investment in life insurance for their future requirements which is said to be forced Investment. So, it has been concluded that making sound investment decision requires both knowledge and skill apart from other factors.
\end{abstract}

Keywords: life insurance, capital formation, monolithic institution, uncertainties, financial cushion, forced investment

\section{Introduction}

Insurance is a cooperative device to spread the loss caused by a particular risk over a number of persons who are expressed to it and who agree to ensure themselves against that risk. It is also a social device that accumulates funds to meet the uncertain losses arising through a certain risk to a person insured against the risk. The process of insurance has been evolved to safeguard the interests of people from uncertainty by providing certainty of payment at a given contingency. The insurance principle comes to be more and more used and useful in modern affairs. Not only does it serve the ends of individuals, or of special groups of individuals, it tends to pervade and to transform modern social order, too.

The origin of insurance is lost in antiquity. The earliest traces of insurances in the ancient world are found in the form of marine trade loans or carriers' contracts which: included an element of insurance. The evidence is on record that arrangements embodying the idea of insurance were made in Babylonia and India at quite an early period. After marine insurance, fire insurance developed in present form. It had been originated in Germany in the beginning of the sixteenth century. The fire insurance got momentum in England after the great fire in 1666 when the fire losses were tremendous. Next, Life insurance made its first appearance in England in sixteenth century, the first recorded evidence in England being the policy on life of Williams Gybbons in 1653. Other miscellaneous Insurance took the present shape at the later part of nineteenth century with the industrial revolution in England. Accident insurance, fidelity insurance, liability insurance and theft insurance were the important form of insurance at that time. Now, general insurance is increasing with the advancement of society, Mishra, M.N., and Mishra, S.B. (2014).

The insurance has become a part of human life. It is not restricted to life, marine or fire only, but has spread over to almost every sphere of human activity. For example, a singer can insure his or her throat, a dancer her legs and an actress her nails etc. So the scope of insurance is unlimited. The significance of the insurance is not only limited to an individual or to a family alone but it has spread over the entire nervous system of a business or say the country as a whole.

\subsection{Insurance is an Investment}

Insurance serves as an agency of capital formation. As institutional investors, insurance companies provide funds to the government and public, and contribute in the economic development of the country. Life insurance is a 
contract providing for payment of a sum of money to the person assured or to his nominee, on the happening of certain events. Various insurance companies offer large number life insurance policies. This is because of the fact that every one of us has different aspirations in life. The ways of life of all individuals being different, the needs and expectations of each person are different from that of the others. Thus, the insurance needs and requirements obviously vary from individuals to individuals. In India, life is projected by a monolithic institution called the Life Insurance Corporation of India (LIC).

Life Insurance Corporation of India (LIC) has made available a number of insurance plans/policies, providing various benefits and offering appropriate options to tone with the requirements of different parties or individuals, Jyotsna Sethi and Nishwan Bhatia (2012). It is with motto of customer orientation which makes possible a fair blending of customer satisfaction and profit generation, Deepak Bhandari and Amit Sharma (2011). Also, it acts as a stabilizer in the share market. The continuous inflow of new funds enables LIC to buy shares when the market is weak, Gajendran, (2011).

Besides, Life Insurance is called an investment because a) it provides protection against risk of early death, b) it can be used as a collateral for taking loans from banks, c) life of key men in an association can be protected, d) it provides tax advantages, e) it is a measure of protection at the time of death because it gives provision for estate duty and f) it is a sum of money received at the end of a particular number of years, i.e., "the termination period of the contract". Life Insurance therefore, called an investment with an element of protection and an element of investment

\section{Growth of Life Insurance Industry and Its Market Share}

The insurance industry of India consists of 53 insurance companies of which 24 are in life insurance business and 29 are non-life insurers. Among the life insurers, Life Insurance Corporation (LIC) is the sole public sector company. With 70.4 per cent contribute to market share in FY16; LIC continues to be the market leader, followed by SBI (5.1 per cent), ICICI (4.9 per cent) and HDFC (4.1 per cent).

- The life insurance market has escalated from US\$10.5 billion in FY02 to US\$27.5 billion in FY16

- Over FY02-FY16, life insurance premiums expanded at a CAGR [Compound Annual Growth Rate] of 7.5 per cent.

- The life insurance industry has the potential to grow 2-2.5 times by 2020 in spite of multiple challenges supported by long-term trends and fundamentals underlying household savings.

The Indian insurance market is a huge business opportunity waiting to be harnessed. India currently accounts for less than 1.5 per cent of the world's total insurance premiums and about 2 per cent of the world's life insurance premiums despite being the second most populous nation. India's life insurance sector is the biggest in the world with about 360 million policies which are expected to increase at a Compound Annual Growth Rate (CAGR) of 12-15 per cent over the next five years. The insurance industry plans to hike penetration levels to five per cent. By, 2020, the total market size of the insurance sector in India is projected to touch US\$ 350-400 billion. The country is the fifteenth largest insurance market in the world in terms of premium volume, and has the potential to grow exponentially in the coming years, Web site, ibef.

India's insurable population is anticipated to touch 750 million in 2020, with life expectancy reaching 74 years. Furthermore, life insurance is projected to comprise 35 per cent of total savings by the end of this decade, as against 26 per cent in 2009-10. The future looks promising for the life insurance industry with several changes in the regulatory framework which will lead to further change in the way the industry conducts its business and engages with its customers. Demographic factors such as growing middle class, young insurable population and growing awareness of the need for protection and retirement planning will support the growth of Indian life insurance, Assocham Report (2015).

\section{Literature Review}

Vipul (2007), the author explored about the comparative study of LIC and found that the consumers are expecting the premium to be reduced and more transparency should between insurers and policy holders, also stressed that company should be customer - centered. Praveen kumar tripathi (2008) constructed his research on the basis of various segments in order to recognize the customer perception and expectation from private insurers. Bhagabat Barik et. al. (2014) discussed the emerging trends in insurance and highlighted that there is a need of highly skilled professional advisory in Indian insurance industry, balanced marketing mix, policy administration and as far as possible re-engineering of the business model. Analyzed the different factors that determine the investment in LI policies and the result given was the trust and, Effective and good plans were the main reasons to invest in LI among the customers, by Babita yadav (2012). Balasubramanyam (2015) focused on the overall 
development of insurance companies in India and proposed that the insurance industry should offer its customers tailor made products to satisfy their financial needs in the future.

\section{Statement of the Problem}

With the growth of professional risk management, the insurance device has become more and more popular these days. The liberalization of the economy has resulted into the availability of large number of alternative products/financial services. This has paved the way for the potential and unconventional entrants to penetrate the financial market through innovative higher products' profile and portfolios, resulting into a sudden spurt in the demand of insurance investments. Life Insurance plays vital role in the field of investment. Investments are both important and useful in the context of present day conditions. It is a common saying "One paisa saved is one paisa earned". In the present financial market the investor are facing either the problem of safety or unattractive returns. At this juncture, the extent to which LIC goes to attract the investors has been undertaken in this study.

\subsection{Scope of the Study}

Life is a roller coaster ride and is full of twists and turns. One cannot take anything for granted in life. Insurance policies are a safeguard against the uncertainties of life. Insurance is system by which the losses suffered by a few are spread over many, exposed to similar risks. Insurance is a protection against financial loss arising on the happening of an unexpected event. Insurance policy helps in not only mitigating risks but also provides a financial cushion against adverse financial burdens suffered. Thus, this paper discussed the investors' behavior towards life Insurance and the study was based on Life Insurance of public sector and limited with policyholders' preference of Thanjavur district.

\section{Results and Methodology}

The insurance has become a part of human life. It is not restricted to life, marine or fire only, but has spread over to almost every sphere of human activity. For example, a singer can insure his or her throat, a dancer her legs and an actress her nails etc. So the scope of insurance is unlimited. The significance of the insurance is not only limited to an individual or to a family alone but it has spread over the entire nervous system of a business or say the country as a whole. This research explores the growth of Life Insurance Corporation of India and behavior of the policyholder of this firm. Specifically, this research addresses the following questions:

- What is the nature of policyholders in the context of socio-economic factors?

- What are the factors influences them to invest in Life Insurance?

- Which factor is closely related to this Investment as per the policyholders?

Both primary and secondary data were used and out of sample 155, 128 policyholders responded the questions in a fair manner and the same has been undertaken for the analysis. The data collected were analyzed and interpreted with the help of statistical tools. The following tables highlight the socio-economic factors of the respondents as well as their preference towards the investment in Life Insurance.

\subsection{Demographic and Other Factors of the Sample Respondents}

Table No 1 reveals the demographic factors of the policyholders/respondents. The factors are analyzed on the basis of gender, age, educational qualifications, occupation, income category and investment in LIC. The table extended with other factors also like duration of premium payment, reasons to select the specific duration, savings other than LIC, duration of investment and source of Information. It is clear from the table that a majority (57.81\%) of the respondents fall in the age group of 41-55years and in gender 108 i.e $72 \%$ are male out of 128 respondents. Majority of the respondents belong to the category of Undergraduates i.e $63.68 \%$, who constitute core group of investors. Occupation-wise, nearly $61.72 \%$ respondents are salaried employees' followed by professionals, business class, retired investors with $16.41 \%, 14.84 \%$ and $7.03 \%$ respectively. Out of 128 respondents, $36.72 \%$ fall under the annual income group of $101-105$ thousands, and 21.88 percent each falls under the annual income group of less than 100 thousands and 151-200 thousands respectively.

It is significant to know from the table that majority of the respondents have opted for taking only one policy i.e $72.65 \%$, followed by taking two policies $21.09 \%$ and $6.26 \%$ of the respondents have taken three policies. No respondents have taken more than three policies. Regarding reasons to invest in LIC, $45.31 \%$ of the respondents considered the safety as a main reason, followed by return factor which cited by $38.28 \%$ and $16.41 \%$ respondents considered liquidity as a motive to Invest in LIC. Out of total respondents, $64.84 \%$ of the respondents were paying their premium on monthly basis, followed by $17.18 \%$ who pay their premium on $\%$ quarterly basis, 7.04 and $10.94 \%$ of the total were paying half-yearly and annual basis respectively. While selecting the specific duration of the premium payment, the majority respondents i.e 101, felt the easy mode of 
payment. The respondents have investments other than LIC like, $63.28 \%$ of the respondents have savings in Bank, 24.22\% have saving in Post Office, 9.37and 3.13\% of the respondents have their savings in Mutual funds and Securities respectively. Duration of investment by the respondents covered below ten years as majority $46.09 \%$ and followed by 11-20years category. Regarding the awareness among the respondents to invest in LIC was a greater part of them known through the agents only.

Table 1. Demographic and other factors of the sample respondents

\begin{tabular}{|c|c|c|c|}
\hline S.NO & Basis & Number of respondents & Percentage \\
\hline \multirow[t]{2}{*}{ Gender } & Male & 108 & 84.38 \\
\hline & Female & 28 & 15.62 \\
\hline \multirow[t]{4}{*}{ Age } & Below 25 years & 4 & 3.13 \\
\hline & $26-40$ & 38 & 29.69 \\
\hline & $41-55$ & 74 & 57.81 \\
\hline & Above 55 & 12 & 9.37 \\
\hline Education & Higher Secondary & 22 & 17.19 \\
\hline \multirow{3}{*}{ Qualifications } & Under Graduate & 81 & 63.28 \\
\hline & Post Graduate & 18 & 14.06 \\
\hline & Professionals & 7 & 5.47 \\
\hline \multirow[t]{4}{*}{ Occupation } & Business & 19 & 14.84 \\
\hline & Professional & 21 & 16.41 \\
\hline & Salaried employees & 79 & 61.72 \\
\hline & Retired & 9 & 7.03 \\
\hline \multirow[t]{4}{*}{ Annual Income in 000' } & Less than 100 & 28 & 21.88 \\
\hline & $101-150$ & 47 & 36.72 \\
\hline & $151-200$ & 28 & 21.88 \\
\hline & Above 200 & 25 & 19.52 \\
\hline \multirow[t]{4}{*}{ No. of Policies Taken } & Only one & 93 & 72.65 \\
\hline & Two policies & 27 & 21.09 \\
\hline & Three policies & 8 & 6.26 \\
\hline & Above three policies & - & 0 \\
\hline \multirow[t]{3}{*}{ Motives to Invest in LIC } & Safety & 58 & 45.31 \\
\hline & Return & 49 & 38.28 \\
\hline & Liquidity & 21 & 16.41 \\
\hline \multirow{4}{*}{$\begin{array}{c}\text { Duration of premium } \\
\text { payment }\end{array}$} & Monthly & 83 & 64.84 \\
\hline & Quarterly & 22 & 17.18 \\
\hline & Half yearly & 9 & 7.04 \\
\hline & Annual & 14 & 10.94 \\
\hline \multirow{3}{*}{$\begin{array}{l}\text { Reasons to select the } \\
\text { specific duration }\end{array}$} & Easy payment & 101 & 78.91 \\
\hline & Affordable amount & 17 & 13.28 \\
\hline & Save time & 10 & 7.81 \\
\hline \multirow[t]{5}{*}{ Savings other than LIC } & Banks & 81 & 63.28 \\
\hline & Post office & 31 & 24.22 \\
\hline & Mutual funds & 12 & 9.37 \\
\hline & Securities & 4 & 3.13 \\
\hline & Company fixed deposits & - & - \\
\hline \multirow[t]{3}{*}{ Duration of investment } & Less than 10 years & 59 & 46.09 \\
\hline & $11-20$ years & 55 & 42.97 \\
\hline & Above 20 years & 14 & 10.94 \\
\hline \multirow[t]{4}{*}{ Source of Information } & Agents & 59 & 46.09 \\
\hline & Advertisement & 47 & 36.72 \\
\hline & Friends & 3 & 2.35 \\
\hline & Own Analysis & 19 & 14.84 \\
\hline
\end{tabular}

Source: Primary data 


\subsection{Investors' Assessment}

It is significant to know from Table 2 that the investors' assessment of their own portfolio and receiving culture of the concern. Out of the respondents $128,49.22 \%$ of them are satisfied with their return due to reasonable performance by their investment as well as the service rendered by the corporation and $16.41 \%$ of the respondents considered the yield from their investment to be good. Only, 9.37\% of the investors consider the services to be very good and $25 \%$ of the respondents considered not satisfactory.

Table 2. Investors' assessment

\begin{tabular}{ccc}
\hline Assessment & $\begin{array}{c}\text { No. of } \\
\text { respondents }\end{array}$ & Percentage \\
\hline Very Good & 12 & 9.37 \\
\hline Good & 21 & 16.41 \\
\hline Satisfactory & 63 & 49.22 \\
\hline Poor & 32 & 25 \\
\hline Total & 128 & 100 \\
\hline
\end{tabular}

Source: Primary data

\subsection{Dissatisfaction towards LIC}

Table 3 shows the dissatisfaction of the respondents towards the service rendered by the corporation. Out of 128 respondents, 32 respondents feel dissatisfaction of service. The majority of their respondents i.e. out of 32,22 respondents feel dissatisfaction because of delay in settlement and 25 respondents feel payment of premium is high. Very negligible percent of the respondents quoted poor public relation.

Table 3. Reasons for dissatisfaction

\begin{tabular}{ccc}
\hline Reasons & $\begin{array}{c}\text { Number of } \\
\text { respondents }\end{array}$ & Percentage \\
\hline Delay in Settlement & 22 & 68.75 \\
\hline Inadequate Information & - & - \\
\hline High Premium & 8 & 25 \\
\hline Poor Public Relation & 2 & 6.25 \\
\hline Total & 32 & 100
\end{tabular}

Source: Primary data

\subsection{Rank Preference in Saving Pattern of the Respondents}

Table 4 depicts the ranking preference in the saving pattern of the respondents. Out of 128 respondents, 54 investors prefer first to invest in insurance. Next, 48 respondents who rank the bank deposit as first and 22 respondents marked investment in the post office as first. Negligible numbers felt investing in mutual funds and securities as first preference. This shows that investment in Insurance and Banks were the main preference exposed by the respondents of this study. 
Table 4. Ranking preference in investment

\begin{tabular}{cccccccc}
\hline Preference/Rank & I & II & III & IV & V & VI & Total \\
\hline Insurance & 54 & 41 & 9 & 16 & 8 & - & 128 \\
\hline Banks & 48 & 44 & 12 & 10 & 8 & 6 & 128 \\
\hline Post office & 22 & 19 & 38 & 31 & 7 & 11 & 128 \\
\hline Mutual funds & 3 & 21 & 29 & 15 & 26 & 34 & 128 \\
\hline Securities & 1 & 3 & 33 & 49 & 17 & 25 & 128 \\
\hline Company fixed deposits & - & - & 7 & 7 & 62 & 52 & 128 \\
\hline Total & 128 & 128 & 128 & 128 & 128 & 128 & \\
\hline
\end{tabular}

\section{Source: Primary Data}

\subsection{Statistical Tools}

The fundamental aim of any research it to establish the relationship between two or more sets of observations to arrive at a reliable conclusion, J.K.Sharma (2004). So, to express the magnitude and the strength of relationship between variables statistical techniques of correlations coefficient have been used.

\section{a. The degree of relationship between age and Investment assessment of the respondents:}

As per Karl Pearson's correlation coefficient, the value of Correlation coefficient between age and investment assessment shows 0.854 . So, the inference can be drawn that there is a high degree of positive correlation between age and Investment assessment of the respondents.

\section{b. The degree of relationship between Education and Investment assessment of the respondents:}

The value of Correlation coefficient between Education qualification and investment assessment shows -0.348. Since the coefficient of correlation is negative -0.348 , it indicates that there is a fairly large inverse correlation between the two variables. Hence, we conclude that there is no association between the educational qualification and the investment assessment of the respondents.

c. The coefficient of multiple correlations: The degree of association between variables of annual income, duration of premium payment and number of policies taken:

The degree of relationship between Annual incomes of the respondents as a dependent variable $(\mathrm{Y})$ and, duration of premium payment $\left(\mathrm{X}_{1}\right)$ and Number of policies taken $\left(\mathrm{X}_{2}\right)$ by the respondents are independent variables. The coefficient of multiple correlations expressed in terms of simple linear correlations: $R=r_{\mathrm{yx} 1}, r_{\mathrm{yx} 2}$ and $r_{\mathrm{x} 1 \times 2}$

Therefore, Multiple Correlations coefficient is defined as:

$$
\begin{gathered}
R=\frac{\sqrt{r_{y x_{1}}^{2}+r_{y x_{2}}^{2}-2 r_{y x_{1}}\left(r_{y x_{2}}\right)\left(r_{x_{1} x_{2}}\right)}}{\sqrt{1-r_{x_{1} x_{2}}^{2}}} \\
\mathbf{R}_{\mathbf{y} \times 1}=.00001, \mathbf{r}_{\mathbf{y x} 2}=-.130 \text { and } \mathbf{r}_{\mathbf{x} 1 \times 2}=.984
\end{gathered}
$$

Therefore, $\mathbf{R}_{\mathbf{y} \times \mathbf{1}} \mathbf{= 0 . 2 7 9}$.

The outcome of $\mathrm{R}_{\mathrm{y} \times 1}=0.279$, shows the degree of association among annual income, duration of premium payment and number of policies taken which are fairly correlated. This can be inferred that investment is not determined by income of the respondents, instead they understood the necessity of investment in life insurance for their future requirements which is said to be forced Investment, Bhole and Jitendra,(2009). Though life insurance is a forced investment, it is for the welfare of the policyholders which is the payment of contingency. 
Since the life insurance contract is a contract of certainty, the contingency of death or the expiry of term will certainly occur, the payment is certain. Thus, from the study it can be conclude that Life Insurance has become a household name providing security for a lifetime of the investors.

\section{Conclusion}

At the outset, the Life insurance offers to the investing public, a wide opportunity to invest. Under various schemes float by it which fulfills the investor's expectations of a risk-free investment. Insurance is a process in which a large number of persons collect their small contribution, called the premium, in a pool and out of their losses are paid to the suffering person. Even in a competitive scenario, LIC has registered the world's highest growth rate and creating history in the insurance sector. LIC strength quick top change with times, responding to changing needs and aspiration of the people. Evidently, LIC today stands as a global stage ever adapting to world-class standards of service in terms of tailor made schemes, computerization and strategic planning. Thus, the study investigates the investor's preferences, and the factors that determines for investing in LIC. Based on the analysis, the study concludes that the success of every investment decision has become increasingly important in recent times. Making sound investment decision require both knowledge and skill apart from other factors. Skill is needed to evaluate risk and return associated with an investment with minimum risk involved if he carefully analysis the information published. Knowledge is required regarding the complex investment alternatives available, in the economic environment.

\section{References}

Babita Yadav, \& Anshuja Tiwari. (2012, July). A study on factors affecting customers investment towards life insurance policies. International Journal of Marketing, Financial Services \& Management Research, 1(7).

Balasubramanyam, K. (2015, April-June). Development of insurance companies in India. International Journal of Academic Research, 2(3).

Bhagabat Barik, \& Rakesh Patra. (2014, June). Emerging trends in insurance - a study in Indian life insurance industry. Journal of Research in Commerce \& Management, 3(6).

Bhole, L.M., \& Jitendra Mahakud. (2009). Financial Institutions and Markets, -Structure, Growth and Innovations. McGraw Hill Education (India) Private Limited, New Delhi, P.14.

Deepak Bhandari, \& Amit Sharma. (2011). Marketing of Services. Vrinda Publications (P) Ltd., P.233.

Gajendran, A. (2011). A Text on Banking Theory -Law and Practice. Vrinda Publications (P) Ltd., P. 316.

Insurance Regulatory and Development Authority of India (IRDA), Note: \# - as per Assocham Report 2015, Media Reports, Press Releases, Press Information Bureau, Union Budget 2016-17.

Jyotsna Sethi, \& Nishwan Bhatia. (2012). Elements of Banking and Insurance. PHI Learning Private Limited, New Delhi, P.207.

Mishra, M.N., \& Mishra, S.B. (2014). Insurance -Principles and Practice. S.Chand \& Company Pvt Ltd., New Delhi, pp. 3-9.

Praveen Kumar Tripathi. (2008). Customer buying behavior with a focus on market segmentation. Retrieved from indianresearchjournals.com/pdf/IJMFSMR/2012/July/9.pdf

Sharma, J. K. (2004). Business Statistics. Pearsons Education Pvt Ltd, New Delhi, P.461

Vipul. (2007). On comparative study of life insurance corporation of India. Retrieved from https://www.scribd.com/doc/21555292/Project-on-LIC-India\#

http://www.ibef.org/industry/insurance-sector-india/showcase. LIC Continues to Dominate Life Insurance Segment.

\section{Copyrights}

Copyright for this article is retained by the author(s), with first publication rights granted to the journal.

This is an open-access article distributed under the terms and conditions of the Creative Commons Attribution license (http://creativecommons.org/licenses/by/4.0/). 